\title{
Forest biomass stocks and dynamics across the subtropical Andes
}

\author{
Cecilia Blundo $^{1}$ (I) | Agustina Malizia ${ }^{1}$ | Lucio R. Maliziaa ${ }^{2}$ | Jeremy W. Lichstein ${ }^{3}$
}

${ }^{1}$ Instituto de Ecología Regional, CONICET, Universidad Nacional de Tucumán, Tucumán, Argentina

${ }^{2}$ Facultad de Ciencias Agrarias, Centro de Estudios Territoriales Ambientales y Sociales, Universidad Nacional de Jujuy, San Salvador de Jujuy, Jujuy, Argentina

${ }^{3}$ Department of Biology, University of Florida, Gainesville, Florida

\section{Correspondence}

Cecilia Blundo, Instituto de Ecología Regional, CONICET, Universidad Nacional de Tucumán, Yerba buena, Tucumán, Argentina. Email: ccblundo@gmail.com

Funding information

Consejo Nacional de Investigaciones

Científicas y Técnicas, Grant/Award

Number: Cooperation International UF-

CONICET 526/15 and PICTO 2014-0059

Associate Editor: Jennifer Powers Handling Editor: Ann Russel

\begin{abstract}
Forest biomass plays an important role in the global carbon cycle. Therefore, understanding the factors that control forest biomass stocks and dynamics is a key challenge in the context of global change. We analyzed data from 60 forest plots in the subtropical Andes (22-27.5 $\mathrm{S}$ and $300-2300 \mathrm{~m}$ asl) to describe patterns and identify drivers of aboveground biomass (AGB) stocks and dynamics. We found that AGB stocks remained roughly constant with elevation due to compensating changes in basal area (which increased with elevation) and plot-mean wood specific gravity (which decreased with elevation). AGB gain and loss rates both decreased with elevation and were explained mainly by temperature and rainfall (positive effects on both AGB gains and losses). AGB gain was also correlated with forest-use history and weakly correlated with forest structure. Mean annual temperature and rainfall showed minor effects on $A G B$ stocks and $A G B$ change (gains minus losses) over recent decades. Although $A G B$ change was only weakly correlated with climate variables, increases in $A G B$ gains and losses with increasing rainfall-together with observed increases in rainfall in the subtropical Andes-suggest that these forests may become increasingly dynamic in the future.
\end{abstract}

Abstract in Spanish is available with online material

\section{KEYWORDS}

biomass dynamics, biomass stocks, forest structure, forest-use history, montane forests, rainfall, temperature

\section{1 | INTRODUCTION}

ForESTS REPRESENT THE LARGEST ABOVEGROUND CARBON STOCK AMONG TERRESTRIAL ECOSYSTEMS and play an important role in the global carbon cycle (Le Quéré et al., 2016). Tropical and subtropical forests account for approximately $70 \%$ of the global forest carbon sink (Pan et al., 2011) and exhibit substantial inter-annual variation in carbon storage, largely driven by temperature and moisture (Wang et al., 2014). Biomass stocks and dynamics depend on environmental conditions (i.e., resource availability) and on forest attributes in terms of quantity (e.g., stem density, basal area) and quality (i.e., functional traits of the community) (Lohbeck, Poorter, Martínez-Ramos, \& Bongers, 2015; Poorter et al., 2017). In tropical forests, stocks of aboveground biomass (AGB) have been mainly related to forest structure and species composition (Baker et al., 2004; Lewis et al., 2013; Malhi et al., 2006) and to a lesser extent to temperature, rainfall, soil fertility, and topography (Clark \& Clark, 2000, Valencia, Condit, Muller-Landau, Hernandez, \& Navarrete, 2009, Álvarez-Dávila et al. 2017). Regional patterns of basal area and plot-mean wood specific gravity have explained more than $80 \%$ of AGB variation across tropical forests 
(Baker et al., 2004; Baraloto et al., 2011; Poorter et al., 2017), which is expected because AGB is inherently related to tree diameter and wood specific gravity. However, structural parameters may differ in their relationships with environmental variation (e.g., climate) and disturbance (Zhang et al., 2015). Thus, a variety of forest structure and AGB patterns may emerge across environmental gradients, with implications for AGB stocks and dynamics at the regional scale.

Forest structure and species composition change along elevation gradients across montane forests. In general, stem density and basal area increase, and tree height decreases from lowland to high-montane forests (Clark, Hurtado, \& Saatchi, 2015; Girardin, Farfan-Rios, et al., 2014). Species composition has shown continuous variation across these complex environmental gradients (Fahey, Sherman, \& Tanner, 2016), and it is possible to distinguish altitudinal vegetation zones (e.g., Kessler, 2000). AGB stock does not show clear patterns along elevation in tropical montane forests. It may increase (Alves et al., 2010, Cuni-Sanchez et al. 2017), decrease (Girardin et al., 2010; Kitayama \& Aiba, 2002; Miyamoto, Sato, Arana Olivos, Clostre Orellana, \& Rohner Stornaiuolo, 2018; Raich, Russell, Kitayama, Parton, \& Vitousek, 2006), or remain relatively constant along altitudinal transects (Culmsee, Leuschner, Moser, \& Pitopang, 2010; Imani et al., 2017; Peña, Feeley, \& Duque, 2018; Unger, Homeier, \& Leuschner, 2012). On the other hand, rates of AGB productivity decrease with elevation, and the causal factors proposed for explaining this pattern include temperature limitation of physiology (Kitayama \& Aiba, 2002), limitation in nutrient uptake (Bruijnzeel, 2004), and cloud cover (Girardin, Malhi, et al., 2014). Structural patterns of forest recovery from disturbance also affect AGB productivity in tropical montane forests (Peña et al., 2018).

Andean forests have been identified as one of the most important hotspots of global biodiversity (Myers, Mittermeier, Mittermeier, Da Fonseca, \& Kent, 2000; Rahbek et al., 2019), and these forests provide important ecosystems services, such as climate regulation (Jarvis \& Mulligan, 2011) and carbon storage (Spracklen \& Righelato, 2014). The interaction between abiotic factors and forest recovery related to land-use change vary across latitudes and elevations, leading to differences in forest structure and productivity between the tropical and subtropical Andes (Báez et al., 2015). Although many studies have analyzed patterns of AGB stocks and dynamics across tropical Andean forests (e.g., Unger et al., 2012, Girardin, Malhi, et al., 2014, Girardin, Farfan-Rios, et al., 2014, Miyamoto et al., 2018, Peña et al., 2018, Vilanova et al., 2018), no studies to date have quantified these patterns in the subtropical Andes.

In this paper, we use inventory data from 60 forest plots (45 of them with two censuses), distributed along elevation (300-2300 m) and latitudinal $\left(22-27.5^{\circ} \mathrm{S}\right)$ gradients in the subtropical Andean forests of Argentina, to quantify patterns in AGB stocks and dynamics in the subtropical Andes. The forest plots represent well-conserved and mature forests, although historical human practices, such as seasonal cattle grazing (hereafter, "grazing") and selective logging have occurred in some plots. We analyze patterns of AGB stocks and AGB dynamics (i.e., AGB change and its components: AGB gain due to growth and recruitment, and AGB loss due to mortality) along elevation and latitudinal gradients. Also, we quantify how AGB stocks and dynamics depend on environmental factors (i.e., climate variables and forest-use history) and forest structural parameters (basal area, stem density of large trees, and plot-mean wood specific gravity). We test the hypotheses that AGB stocks and AGB dynamics are positively related to temperature (Girardin et al., 2010; Sullivan et al., 2020) and water availability (Álvarez-Dávila et al. 2017), and that AGB dynamics are related to forest structure (Lohbeck et al., 2015; Poorter et al., 2017).

\section{2 | METHODS}

Andean forests of northwest Argentina represent the southernmost extension of Neotropical montane forests (Cabrera \& Willink, 1980). In this part of the Andes, climate is defined as subtropical, with a marked dry season (April-October) and occasional frost during cold months (Brown, Grau, Malizia, \& Grau, 2001). Mean annual temperature decreases from $21.5^{\circ} \mathrm{C}$ to $11.5^{\circ} \mathrm{C}$ along the altitudinal gradient, and rainfall ranges from 800 to more than $2000 \mathrm{~mm}$ annually, being higher on slopes with eastern exposures (Arias \& Bianchi, 1996). In addition, water input through fog interception may be as important as direct rainfall in low- and highmontane forests (Hunzinger, 1997). Based on floristic composition, three forest types are differentiated along the elevation gradient: premontane forest from ca. 400 to $800 \mathrm{~m}$ asl; low-montane forest from ca. 800 to $1,500 \mathrm{~m}$ asl; and high-montane forest from ca. 1,500 to $2,500 \mathrm{~m}$ asl; montane grasslands occur above tree line (Brown et al., 2001). Besides forest conversion to agriculture in the lowlands, grazing and selective logging have been the principal human activities in these montane forests during the last centuries (Brown et al., 2001).

\section{1 | Forest inventory plots}

Plots were established between 300 and 2,300 m asl, and between $22^{\circ}$ and $27.5^{\circ} \mathrm{S}$ (Figure S1) to cover the wide environmental variation of the subtropical Andes (e.g., temperature, rainfall, slope, and aspect). Plot establishment and measurement were performed between 2002 and 2017 (Table S1), and followed standardized protocols for Andean forests (Osinaga-Acosta et al., 2014). We analyzed inventory data from 60 permanent plots, 45 of them measured twice with a mean of 6.6 years between censuses (29 plots with 4-6 years between census 1 and 2, and 16 plots with 9-10 years between census 1 and 2). The 60 plots include 531 -ha plots (51 rectangular plots of $20 \times 500 \mathrm{~m}$ and two square plots of $100 \times 100 \mathrm{~m}$ ), four 0.4-ha plots (two $40 \times 100 \mathrm{~m}$ and two $20 \times 200 \mathrm{~m}$ ), two 0.24 -ha plots $(40 \times 60 \mathrm{~m})$, and one 6 -ha plot $(200 \times 300 \mathrm{~m})$. All stems with diameter at $1.3 \mathrm{~m}$ height (diameter at breast height, $\mathrm{DBH}) \geq 10 \mathrm{~cm}$ were marked, identified, and DBH measured. These inventoried stems included single-stemmed trees, as well as stems 
of multi-stemmed individuals that forked below $1.3 \mathrm{~m}$ height. We marked and measured a total of 28,983 stems belonging to 154 species. Nearly all trees were identified to the species level, with $0.38 \%$ of individuals identified to the genus level, and $0.12 \%$ of individuals unidentified.

Plots were established in well-conserved and mature forests. However, some plots have occasional grazing; this does not seem to reduce forest biomass but may affect species composition after decades of forest use (Blundo et al., 2018). In addition, some plots had low-intensity selective logging prior to the initial census. Forests in this region with low-intensity logging largely recover to their pre-logging condition, in terms of forest structure and species composition, within 20 years (Blundo, Malizia, \& GonzálezEspinosa, 2015). In summary, 48 out of 60 plots were old-growth forests ( 28 with grazing and 20 without), and 12 out of 60 plots were forests with low-intensity logging ( $>20$ years since the last selective logging) (Table S1).

For each plot, we obtained climatic data at $1-\mathrm{km}$ resolution from the CHELSA database (Karger et al., 2017). To describe the climate gradient in terms of environmental energy and water availability, we used mean annual temperature (MAT), temperature seasonality (TS), annual rainfall, and rainfall seasonality (RS). We obtained wood specific gravity (WSG) for $74 \%$ of species using local databases (Easdale, Healey, Grau, \& Malizia, 2007, INTI-CITEMA 2007; https://www.inti.gob.ar/publicaciones/desca rgac/365), and we used an international database when local data were unavailable (Chave et al., 2006). For unidentified individuals, we used the plot-mean WSG value (see details below) of the plot where that individual occurred

We calculated plot-level basal area, stem density of large trees, and plot-mean WSG to describe forest structure of each plot. Basal area of individual trees was calculated as: $\mathrm{BA}=\pi / 4 \times \mathrm{DBH}^{2}$. Treelevel BA values $\left(\mathrm{m}^{2}\right)$ were summed to estimate plot-level $B A\left(\mathrm{~m}^{2} / \mathrm{ha}\right)$. Stem density of large trees (SD50) is the density of all stems $\geq 50 \mathrm{~cm}$ in DBH measured in the plot (stem/ha). Plot-mean WSG (WSG $\mu$ ) in each plot was calculated by weighting the WSG of each species (g/ $\mathrm{cm}^{3}$ ) by its plot basal area.

AGB was estimated from the equation developed by Chave et al. (2014) for cases where tree height was unavailable (as is this case): $A G B=\exp (-1.803-0.976 \times E+0.976 \times \ln (W S G)+$ $\left.2.673 \times \ln (\mathrm{DBH})-0.0299 \times(\ln (\mathrm{DBH}))^{2}\right)$. The environmental factor $\mathrm{E}$ was calculated from plot-level climate variables as follows: $E=(0.178 \times$ Temperature seasonality-0.938 $\times$ Climatic Water Deficit-6.61 $\times$ Precipitation seasonality) $\times 10^{-3}$ ). We extracted the Climatic Water Deficit index from Chave et al. (2014) (http://chave.upstlse.fr/pantropical_allometry.htm). Tree-level AGB values (Mg biomass) were summed to estimate plot-level AGB (Mg biomass/ha).

To quantify AGB dynamics within each plot, we calculated plotlevel AGB change, AGB loss, and AGB gain (Mg biomass/ha/yr). AGB change $=\left(A G B_{2}-A G B_{1}\right) / T$, where $A G B_{1}$ and $A G B_{2}$ are $A G B$ at the time of the first and second measurements, respectively, and $T$ is the census interval (years). AGB loss (due to tree mortality) is the AGB of trees alive at time 1 but dead at time 2, annualized by T. Finally, based on the formula for $A G B$ dynamics, $A G B_{2}=A G B_{1}+(A G B$ gain$A G B$ loss) $\times T$, we obtained annualized $A G B$ gain (due to tree recruitment and growth), as: $A G B$ gain $=\left(A_{G B}-A G B_{1}\right) / T+A G B$ loss.

\section{2 | Data analysis}

We calculated Spearman rank correlations $(\rho)$ to evaluate relationships among spatial variables (i.e., elevation, latitude), climate variables (i.e., MAT, TS, annual rainfall, RS), forest structure variables (i.e., BA, SD50, WSG $\mu$ ), AGB stocks, and AGB dynamics variables (i.e., $A G B$ change, $A B G$ gain, and $A G B$ loss). To determine which environmental variables (i.e., climate variables and forest-use history) were related to AGB stocks, and which environmental and forest structure variables were related to $A G B$ gain and loss, we fitted a series of nested generalized linear models (GLM). First, we evaluated the relationship between spatial variables (elevation and latitude) and AGB stocks, AGB gain, and AGB loss (i.e., Null model versus Spatial model, where "Null" refers to an intercept-only model). Second, to test the hypothesis that AGB stocks and AGB dynamics are positively related to temperature and water availability, we compared the spatial model with each climate variable (i.e., Spatial model versus Spatial + Climate model). Then, to evaluate if forest structure variables (i.e., BA, SD50 and WSG $\mu$ ) explain additional variance in AGB gain and AGB loss, we compared the spatial + climate model with each forest structure variable (i.e., Spatial + Climate model versus Spatial + Climate + Forest structure model). Finally, we analyzed the effects of forest-use history (i.e., old-growth forests, old-growth forests with grazing, and forests with past logging) on AGB stocks, AGB gain and AGB loss. We used the Gaussian family in all models, and we log-transformed $A G B$ gain and $A G B$ loss to normalize variables. Comparisons between nested models were performed with likelihood ratio tests. All analyses were performed in R ( $R$ Core Team 2020).

\section{RESULTS}

Forest structure showed clear patterns along the environmental gradient of subtropical Andean forests, in which temperature decreases and rainfall seasonality (RS) increases with elevation (Table S2). Basal area increased with elevation and increased slightly with latitude, and WSG $\mu$ decreased with elevation and with latitude (Figure 1a-b, Table S2). AGB stocks remained relatively constant along the elevation gradient and increased with latitude (Figure 1c, Table S2). The mean AGB stock was $324 \mathrm{Mg}$ biomass/ha, and the range was 140 to $522 \mathrm{Mg}$ biomass/ha. The latitudinal trend in AGB stocks was significant (Table 1) with a slight increase of AGB stocks toward southern forests ( $310 \pm 12 \mathrm{Mg}$ biomass/ha in northern plots; $376 \pm 23 \mathrm{Mg}$ biomass/ha in southern plots; \pm values are standard error). AGB stock was correlated with basal area $(\rho=0.61)$ and stem density of large trees (SD50; $\rho=0.71$ ), but not correlated with WSG $\mu$ (Figure 1d-f). AGB stock was not significantly related to climate variables or forest-use history (Table 1). 
Mean AGB gain (recruitment plus growth) was $4.9 \mathrm{Mg}$ biomass/ ha/yr (range 1.2 to $12.1 \mathrm{Mg}$ biomass/ha/yr), and mean AGB loss was $5.0 \mathrm{Mg}$ biomass/ha/yr (range 0.9 to $15.7 \mathrm{Mg}$ biomass/ha/ yr). Mean AGB change was $-0.1 \mathrm{Mg}$ biomass/ha/yr (range -9.9 to $6.4 \mathrm{Mg}$ biomass/ha/yr). AGB change was relatively constant along elevation and latitudinal gradients (Figure 2a), and none of the climate or forest structure variables were correlated with $A G B$ change (Table S2). AGB gain and AGB loss decreased along altitudinal gradient (Figure $2 \mathrm{~b}-\mathrm{c}$ ). Elevation explained $18 \%$ of AGB gain variance, and $12 \%$ of $A G B$ loss variance (Table 1 ). When climate variables were added to the elevation model, mean annual rainfall had the highest explanatory power for both AGB gain and loss (Table 1). MAT did not significantly improve the elevation models for AGB gain or loss, but the strong negative correlation between MAT and elevation (Table S2) suggests a role for MAT in the elevation effect. Forest structure also contributed to explaining variance in AGB gain: including SD50 (density of trees with DBH $\geq 50 \mathrm{~cm}$ ) in the model increased the explained variation from $24 \%$ to $29 \%$, a marginally significant improvement ( $p=.06$; Table 1). By itself, SD50 was negatively but not significantly correlated with AGB gain (Table S2). Forest structure did not significantly increase variance explained in AGB loss. Finally, forest-use history significantly improved the model for AGB gain, with grazing and past logging both leading to reduced $A G B$ gain (Figure $2 b$, Table 1 ). Forests with a history of grazing and logging also appeared to have reduced AGB loss rates (Figure $2 \mathrm{c}$ ), but these effects were not significant in the AGB loss model (Table 1).

\section{4 | DISCUSSION}

We analyzed patterns of forest structure and their correlations with AGB stock and AGB dynamics across environmental gradients in the subtropical Andean forests in Argentina. We found that the pattern of increasing basal area and stem density of large trees, and decrease in $W S G \mu$, resulted in a relatively constant AGB stock along the altitudinal gradient. Temperature and rainfall explained significant variation in AGB gain and loss, but not in AGB stocks. Forest structure explained some of the variation in AGB dynamics, with $A G B$ gain decreasing with increasing the density of large trees. Finally, forestuse history did not explain differences in AGB stocks or loss rates, but rates of AGB gain in undisturbed old-growth forest were higher than in forests with grazing or past logging.

\section{1 | Forest structure along subtropical Andes}

AGB stocks in subtropical Andean forests were not strongly related to elevation or climate variables. Temperature and water availability may drive large changes in forest structure and species composition along

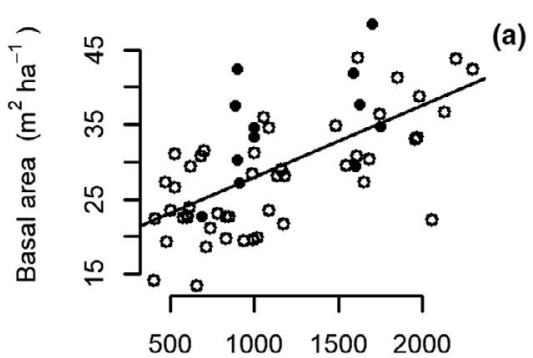

Elevation ( $\mathrm{m}$ asl)

(d)

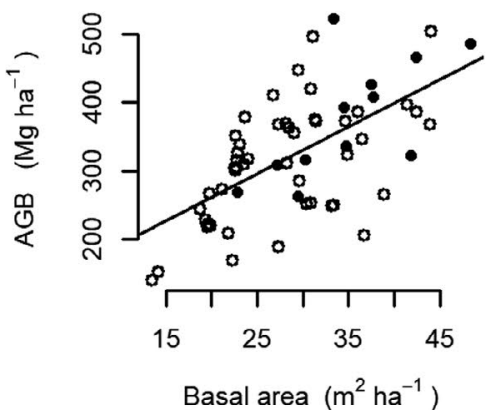

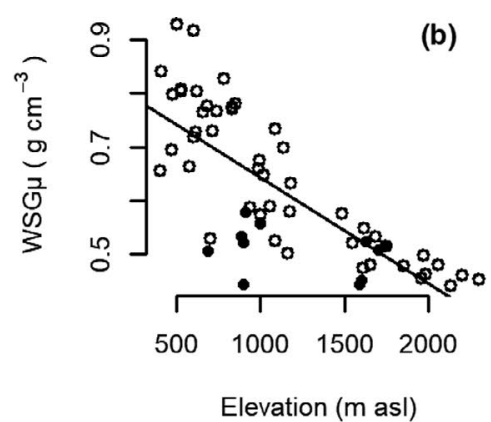

(e)

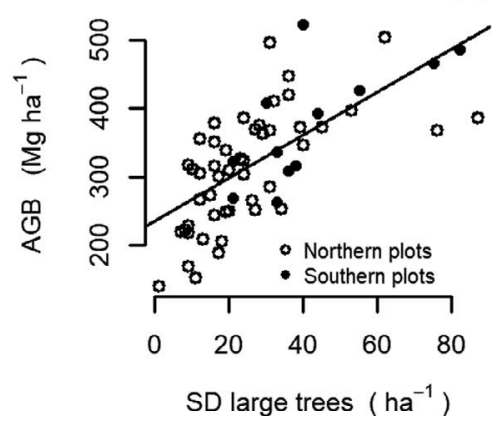

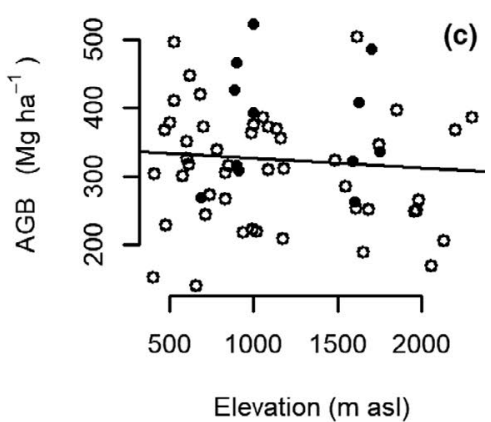

Elevation ( $m$ asl)

FIGURE 1 Altitudinal and latitudinal patterns of forest structure in 60 forest plots across the subtropical Andes (a-c), and associations between forest structure variables and AGB stocks (d-f). WSG $\mu=$ plot-mean wood specific gravity; AGB = aboveground biomass; SD large trees = stem density of trees with $\mathrm{DBH} \geq 50 \mathrm{~cm}$ 
TABLE 1 Summary of comparisons between nested models of aboveground biomass (AGB) stocks and AGB gain and loss rates

\begin{tabular}{|c|c|c|c|c|c|c|c|}
\hline Model & AIC & $\sim 1$ & $\sim$ Lat & $\sim$ Elev & $\sim$ Elev + Rain & $\begin{array}{l}\sim \text { Elev + Rain } \\
+ \text { SD50 }\end{array}$ & $\begin{array}{l}\text { Pseudo } \\
R^{2}\end{array}$ \\
\hline \multicolumn{8}{|l|}{ AGB stocks } \\
\hline$\sim$ Elevation & 712.3 & 0.51 & & & & & \\
\hline$\sim$ Latitude & 708.2 & 0.03 & & & & & 0.07 \\
\hline$\sim$ Latitude + MAT & 709.5 & & 0.41 & & & & \\
\hline$\sim$ Latitude + Rain & 708.7 & & 0.21 & & & & \\
\hline$\sim$ Latitude + TS & 710.2 & & 0.77 & & & & \\
\hline$\sim$ Latitude + RS & 710.1 & & 0.69 & & & & \\
\hline$\sim$ Latitude + FUH & 707.9 & & 0.12 & & & & \\
\hline$\sim$ Latitude & 212.2 & 0.88 & & & & & \\
\hline$\sim$ Elevation + MAT & 204.8 & & & 0.42 & & & \\
\hline$\sim$ Elevation + Rain & 201.8 & & & 0.05 & & & 0.24 \\
\hline$\sim$ Elevation + TS & 205.4 & & & 0.79 & & & \\
\hline$\sim$ Elevation + RS & 205.2 & & & 0.63 & & & \\
\hline$\sim$ Elevation + Rain +BA & 203.8 & & & & 0.83 & & \\
\hline$\sim$ Elevation + Rain +WSG $\mu$ & 203.6 & & & & 0.66 & & \\
\hline$\sim$ Elevation + Rain +SD50 & 200.5 & & & & 0.06 & & 0.29 \\
\hline$\sim$ Elevation + Rain & 223.8 & & & 0.03 & & & 0.21 \\
\hline$\sim$ Elevation + TS & 228.5 & & & 0.96 & & & \\
\hline$\sim$ Elevation + RS & 224.4 & & & 0.04 & & & 0.19 \\
\hline$\sim$ Elevation + Rain + BA & 224.3 & & & & 0.23 & & \\
\hline$\sim$ Elevation + Rain + WSG $\mu$ & 225.3 & & & & 0.46 & & \\
\hline$\sim$ Elevation + Rain + SD50 & 224.6 & & & & 0.28 & & \\
\hline$\sim$ Elevation + Rain + FUH & 225.7 & & & & 0.35 & & \\
\hline
\end{tabular}

Note: Each row in the table represents a different model for AGB stocks, gain, or loss. The first column indicates the explanatory variables included in the model, with " 1 " (intercept-only) being the null model. The remaining columns give the AIC (Akaike information criterion), the description of the nested models used for the Likelihood Ratio tests ( $p$-values are indicated for each test), and the Pseudo- $R^{2}$ for significant models ((Null Deviance Residual Deviance)/ Null Deviance $\times 100$ ).

Abbreviations: MAT, mean annual temperature; Rain, annual rainfall; TS, temperature seasonality; RS, rainfall seasonality; BA, basal area; WSG $\mu$, plotmean wood specific gravity; SD50, stem density of large trees ( $\geq 50 \mathrm{~cm} \mathrm{DBH})$; FUH, forest-use history.

elevation gradients (Fahey et al., 2016), and different patterns of forest structure have been reported across tropical montane forests. Clark et al. (2015) suggested that elevational transects from warm and wet lowland forests to cool and dry montane forests may show different patterns in forest structure than elevational transects from warm and dry lowland forests to cool and moist montane forests. Therefore, different altitudinal patterns of forest structure and species composition may combine to yield different trends in AGB stocks across tropical montane forests, for example, increasing, decreasing, or constant AGB with elevation. For example, in the Peruvian Andes, the lack of trend in basal area with elevation suggests that $A G B$ decline is driven by reduced tree height with increasing elevation (Girardin, Farfan-Rios, 


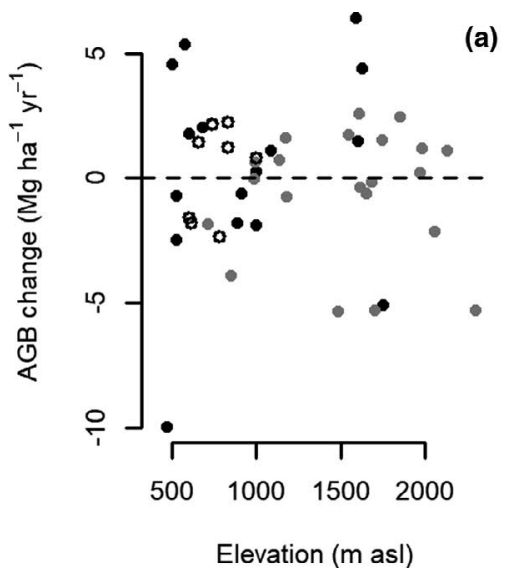

a)

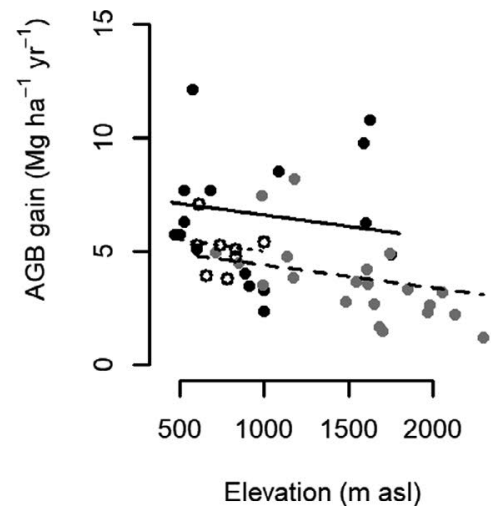

(c)

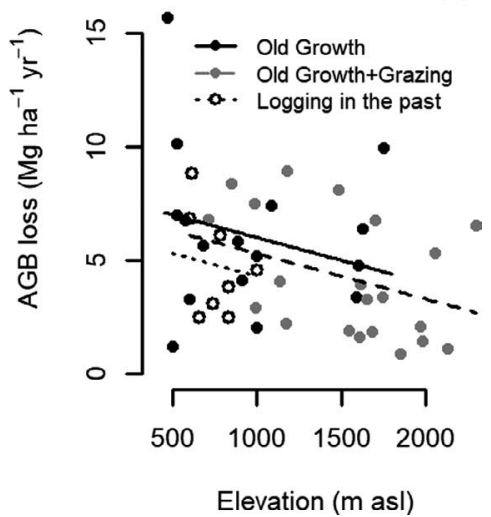

FIGURE 2 Altitudinal and latitudinal patterns of AGB change (a), AGB gain (b), and AGB loss (c), classified by forest-use history in 45 remeasured forest plots across the subtropical Andes

et al., 2014). In contrast, in tropical montane forests of Indonesia, canopy height decreased as basal area increased with elevation, such that AGB stocks were relatively constant along the elevation gradient (Culmsee et al., 2010). In the subtropical Andes, we found compensating changes across elevation in basal area and species composition (in terms of community-mean wood specific gravity, WSG $\mu$ ); that is, low basal area and high WSG $\mu$ in premontane forests resulted in an AGB that was similar to that in high-montane forests with high basal area and low WSG $\mu$. A similar trade-off between forest structure and species composition has previously been reported in tropical montane forests (Culmsee et al., 2010).

In our study area, the decreasing WSG $\mu$ with increasing elevation may be related to the biogeographic origins of trees species. Premontane forests (high WSG $\mu$ ) share a high fraction of species with seasonal tropical forests, such as Caatinga and Atlantic coastal forests in Brazil (Werneck, Costa, Colli, Prado, \& Sites, 2011), in which WSG of trees tends to be higher than $0.7 \mathrm{~g} / \mathrm{cm}^{3}$ on average (Chave et al., 2006). In contrast, high-montane forests (low WSG $\mu$ ) have a high fraction of species of austral and boreal origin (e.g., Podocarpus and Alnus; Brown et al., 2001) that have low WSG $\left(\sim 0.5 \mathrm{~g} / \mathrm{cm}^{3}\right)$. Little is known about patterns of wood density of species along elevation gradients (Clark et al., 2015), and to our knowledge, only Chave et al. (2006) have reported a decrease in species WSG with increasing elevation in the central Andes. We found the same pattern in the southern Andes.

\section{2 | Drivers of forest dynamics}

In our study, AGB gain and loss rates were highest in premontane forests around $500 \mathrm{~m}$ asl, where temperature was highest. Elevation is a complex gradient along which several biotic and abiotic factors are correlated (Ashton, 2003; Kitayama, 1992). Although elevation and MAT were correlated with AGB gain and loss (Table 1 and Table S2), unmeasured variables (such as fog, light incidence, and relative humidity) that vary with elevation may also play a role in determining AGB gain and loss rates. Elevation explained $18 \%$ of $A G B$ gain and $12 \%$ of AGB loss, with both rates decreasing with elevation (and increasing with MAT). Rainfall, which was not significantly correlated with elevation in our study, also explained additional variation in AGB gain and loss (both positively correlated with rainfall).

We hypothesized that forest structure would affect AGB gain and loss; however, neither of these rates was strongly correlated with forest structure variables. The only significant forest structure variable in our multiple regression models was the stem density of large trees (SD50), which increased with elevation (Table S2) and explained about $5 \%$ of AGB gain (increasing the model $R^{2}$ from $24 \%$ to $29 \%$; Table 1 ). Rates of biomass growth increase with tree size in many species (Stephenson et al., 2014), but it is well known that tree growth rates often decrease with elevation (Coomes \& Allen, 2007; Rapp et al., 2012). In our study, AGB gain decreased with elevation even though large trees were relatively abundant in high-montane forests. AGB gain was positively correlated with WSG $\mu$ in our study (Table S2). That is, AGB gain was relatively high in premontane forests (low elevation and high WSG $\mu$ ). Poorter et al. (2017) reported that high plot-mean WSG increases AGB gain, and they argue that high stand-level WSG indicates dominance of shade-tolerant trees with less volumetric growth. In premontane forests, tree species with high WSG and high rates of DBH growth are canopy dominants (e.g., Anadenanthera colubrina, Myracrodruon urundeuva, and Myroxylon peruiferum, Blundo et al., 2015). Our results suggest that the main determinants of AGB dynamics (gain and loss rates) are abiotic variables (e.g., MAT and/or other factors that covary with elevation), but forest structure and species composition may also affect AGB dynamics to some degree.

\section{3 | Forest-use history in subtropical Andean forests}

Our forest plots were established in mature forests with minimal disturbance and, to the extent possible, represent the original subtropical Andean forest vegetation. None of the forests included in this study were recovering in post-agriculture areas. In comparison with the tropical Andes, in which the reported AGB stocks range from 150 to $250 \mathrm{Mg}$ biomass/ha (e.g., Girardin, Farfan-Rios, et al., 2014; Peña et al., 2018; Vilanova et al., 2018), we found that subtropical 
Andean forests had 320 to $370 \mathrm{Mg}$ biomass/ha. Subtropical Andean forests had AGB stocks that were similar as subtropical forests outside the Andes, such as subtropical Atlantic forests in South America (Blundo et al., 2018; Vieira et al., 2008). The abundance of species with high wood specific gravity may contribute to the high AGB stocks of subtropical forests. Tree species composition (and therefore community-mean WSG) differed between tropical and subtropical Andean forests, due to the influence of different floristic regions (Malizia et al., 2020).

Subtropical Andean forests have a long history of use, spanning more than 2000 years of documented occupation (Ortiz, Ramos, \& Alavar, 2017) that has intensified over the last 200 years (Brown et al., 2001). Selective logging and grazing are the principal human activities in these subtropical montane forests that do not involve total deforestation. Forest-use history in our plots did not affect AGB stocks along the elevation gradient; however, plots established in undisturbed old-growth forests had higher rates of AGB gain than old-growth forests with grazing. Few studies have evaluated the effects of this historical human practice on forest structure and dynamics at the community level, but the change in species composition may be partially explained by cattle presence (Blundo, Malizia, Blake, \& Brown, 2012). Cattle presence does not seem to reduce AGB stock but leads to changes in species composition after decades of forest-use, for example, increased abundance of some understory species (Malizia, Easdale, \& Grau, 2013) or increased abundance of evergreen species (Blundo et al., 2018). Additional studies about the effects of this historical human influence would lead to a better understanding of forest dynamics in the subtropical Andes.

\subsection{Study limitations and conclusions}

The capacity to evaluate the effect of climate in this study was limited to some extent by lack of data on climate factors that can be important in montane forests, for example, cloud cover, water input from fog, and solar irradiance. Also, without plot-level instrumentation available, we relied on a global climate product, which may be especially error-prone in mountainous regions. Another limitation of our study concerns the area and time-period (60 total plots; 45 remeasured with a mean census of interval of 6.6 years). Most of the 60 plots were 1 ha in size, and six plots were smaller than 1 ha. Even in the 1-ha plots, the stochastic nature of mortality (e.g., the death of a single large tree, or the absence of canopy mortality during a census interval) could create variance that is not representative of the broader landscape (Chambers et al., 2013). Increasing the sampled area and/or time-period should allow for more robust estimates of AGB stocks and dynamics.

Despite the above limitations, our results provide the first quantification of $A G B$ stocks and rates of $A G B$ gain and loss for a complete elevation gradient across subtropical Andean forests. Over recent decades, mean rainfall and rainfall variability have both increased in northwest Argentina (Ferrero \& Villalba, 2019). Our results suggest that both AGB gain and loss rates will increase if the rainfall trends observed over recent decades continue into the future. This implies the potential for increasing dynamism of subtropical Andean forests. The potential impacts of this dynamism on ecosystem properties (e.g., species diversity; Phillips, Hall, Gentry, Sawyer, \& Vásquez, 1994) are the important topic for future research.

\section{ACKNOWLEDGMENTS}

We thank K. Buzza for making the map, L. Cristobal for facilitating climate data and E. Araoz for statistical support. We thank CONICET funds (Cooperation International UF-CONICET 526/15, and PICTO 2014-0059).

\section{DATA AVAILABILITY STATEMENT}

Data available from the Dryad Digital Repository: https://doi. org/10.5061/dryad.0p2ngf1z0 (Blundo, Malizia, Malizia, \& Lichstein, 2020).

\section{ORCID}

Cecilia Blundo iD https://orcid.org/0000-0002-0227-7316

\section{REFERENCES}

Álvarez-Dávila, E., Cayuela, L., González-Caro, S., Aldana, A. M., Stevenson, P. R., Phillips, O., Rey-Benayas, J. M. (2017). Forest biomass density across large climate gradients in northern South America is related to water availability but not with temperature G. Bohrer (Ed.). PLoS One 12, e0171072.

Alves, L. F., Vieira, S. A., Scaranello, M. A., Camargo, P. B., Santos, F. A., Joly, C. A., \& Martinelli, L. A. (2010). Forest structure and live aboveground biomass variation along an elevational gradient of tropical Atlantic moist forest (Brazil). Forest Ecology and Management, 260, 679-691.

Arias, M., \& Bianchi, A. R. (1996). Estadísticas climatológicas de la Provincia de Salta. Provincia de Salta: Dirección de Medio Ambiente y Recursos Naturales.

Ashton, P. S. (2003). Floristic zonation of tree communities on wet tropical mountains revisited. Perspectives in Plant Ecology, Evolution and Systematics, 6, 87-104.

Báez, S., Malizia, A., Carilla, J., Blundo, C., Aguilar, M., Aguirre, N., ... Feeley, K. J. (2015). Large-scale patterns of turnover and basal area change in Andean forests. PLoS One, 10, e0126594. https://doi. org/10.1371/journal.pone.0126594

Baker, T. R., Phillips, O. L., Malhi, Y., Almeida, S., Arroyo, L., Fiore, D. I., ... Vásquez Martínez, R. (2004). Variation in wood density determines spatial patterns in Amazonian forest biomass. Global Change Biology, 10, 545-562.

Baraloto, C., Rabaud, S., Molto, Q., Blanc, L., Fortunel, C., Hérault, B., ... Fine, P. V. A. (2011). Disentangling stand and environmental correlates of aboveground biomass in Amazonian forests. Global Change Biology, 17, 2677-2688.

Blundo, C., Gasparri, I., Malizia, A., Clark, M., Gatti, G., Campanello, P. I., ... Goldstein, G. (2018). Relationships among phenology, climate and biomass across subtropical forests in Argentina. Journal of Tropical Ecology, 34, 93-107.

Blundo, C., Malizia, A., Malizia, L. R., \& Lichstein, J. W. (2020). Data from: Forest biomass stocks and dynamics across the subtropical Andes. Dryad Digital Repository,https://doi.org/10.5061/dryad.0p2ngf1z0

Blundo, C., Malizia, L. R., Blake, J. G., \& Brown, A. D. (2012). Tree species distribution in Andean forests: Influence of regional and local factors. Journal of Tropical Ecology, 28, 83-95. 
Blundo, C., Malizia, L. R., \& González-Espinosa, M. (2015). Distribution of functional traits in subtropical trees across environmental and forest use gradients. Acta Oecologica, 69, 96-104.

Brown, A. D., Grau, H. R., Malizia, L. R., \& Grau, A. (2001). Argentina. In M. Kappelle, \& A. D. Brown (Eds.), Bosques nublados del Neotrópico (pp. 623-659). San José: Instituto Nacional de Biodiversidad.

Bruijnzeel, L. A. (2004). Hydrological functions of tropical forests: Not seeing the soil for the trees? Agriculture, Ecosystems \& Environment, 104, 185-228.

Cabrera, A., \& Willink, A. (1980). Biogeografía de América Latina, 2nd ed. Washington, DC: OEA.

Chambers, J. Q., Negron-Juarez, R. I., Marra, D. M., Di Vittorio, A., Tews, J., Roberts, D., ... Higuchi, N. (2013). The steady-state mosaic of disturbance and succession across an old-growth Central Amazon forest landscape. Proceedings of the National Academy of Sciences of the United States of America, 110, 3949-3954.

Chave, J., Muller-Landau, H. C., Baker, T. R., Easdale, T. A., ter Steege, H., $\&$ Webb, C. O. (2006). Regional and phylogenetic variation of wood density across 2456 neotropical tree species. Ecological Applications, 16, 2356-2367.

Chave, J., Réjou-Méchain, M., Búrquez, A., Chidumayo, E., Colgan, M., Delitti, W., ... Vieilledent, G. (2014). Improved allometric models to estimate the aboveground biomass of tropical trees. Global Change Biology, 20, 3177-3190.

Clark, D. B., \& Clark, D. A. (2000). Landscape-scale variation in forest structure and biomass in a tropical rain forest. Forest Ecology and Management, 137, 185-198.

Clark, D. B., Hurtado, J., \& Saatchi, S. S. (2015). Tropical rain forest structure, tree growth and dynamics along a 2700-m elevational transect in Costa Rica. PLoS One, 10, e0122905.

Coomes, D., \& Allen, R. (2007). Effects of size, competition and altitude on tree growth. Journal of Ecology, 95, 1084-1097.

R Core and Team (2020). R: A language and environment for statistical computing. Vienna, Austria: R Foundation for Statistical Computing.

Culmsee, H., Leuschner, C., Moser, G., \& Pitopang, R. (2010). Forest aboveground biomass along an elevational transect in Sulawesi, Indonesia, and the role of Fagaceae in tropical montane rain forests. Journal of Biogeography, 37, 960-974. https://doi. org/10.1111/j.1365-2699.2009.02269.x

Cuni-Sánchez, A., Pfeifer, M., Pompeu, P., Marchant, R., Calders, K., Sørensen, C., ... Burgess, N. (2017). New insights on above ground biomass and forest attributes in tropical montane forests. Forest Ecology and Management, 399, 235-246.

Easdale, T. A., Healey, J. R., Grau, H. R., \& Malizia, A. (2007). Tree life histories in a montane subtropical forest: Species differ independently by shade-tolerance, turnover rate and substrate preference. Journal of Ecology, 95, 1234-1249. https://doi. org/10.1111/j.1365-2745.2007.01290.x

Fahey, T. J., Sherman, R. E., \& Tanner, E. V. J. (2016). Tropical montane cloud forest: Environmental drivers of vegetation structure and ecosystem function. Journal of Tropical Ecology, 32, 355-367.

Ferrero, M. E., \& Villalba, R. (2019). Interannual and long-term precipitation variability along the subtropical mountains and adjacent Chaco $\left(22-29^{\circ} \mathrm{S}\right)$ in Argentina. Frontiers in Earth Science, 7, 148. https://doi. org/10.3389/feart.2019.00148

Girardin, C., Farfan-Rios, W., Garcia, K., Feeley, K., Jørgensen, P., Murakami, A. A., ... Malhi, Y. (2014). Spatial patterns of above-ground structure, biomass and composition in a network of six Andean elevation transects. Plant Ecology \& Diversity, 7, 161-171.

Girardin, C., Malhi, Y., Aragão, L., Mamani, M., Huasco, W. H., \& Durand, L. (2010). Net primary productivity allocation and cycling of carbon along a tropical forest elevational transect in the Peruvian Andes. Global Change Biology, 16, 3176-3192.

Girardin, C., Malhi, Y., Feeley, K., Rapp, J., Silman, M., Meir, P., ... Aragão, L. E. (2014). Seasonality of above-ground net primary productivity along an Andean altitudinal transect in Peru. Journal of Tropical Ecology, 30, 503-519.

Hunzinger, H. (1997). Hydrology of Montane Forests in the Sierra de San Javier, Tucuman, Argentina. Mountain Research and Development, 17, 299-308.

Imani, G., Boyemba, F., Lewis, S., Nabahungu, N. L., Calders, K., Zapfack, L., ... Cuni-Sanchez, A. (2017). Height-diameter allometry and above ground biomass in tropical montane forests: Insights from the Albertine Rift in Africa. PLoS One, 12(6), e0179653. https://doi. org/10.1371/journal.pone.0179653

Jarvis, A., \& Mulligan, M. (2011). The climate of cloud forests. Hydrological Processes, 25, 327-343.

Karger, D. N., Conrad, O., Böhner, J., Kawohl, T., Kreft, H., Soria-Auza, R. W., ... Kessler, M. (2017). Climatologies at high resolution for the earth's land surface areas. Scientific Data, 4, 170122.

Kessler, M. (2000). Elevational gradients in species richness and endemism of selected plant groups in the central Bolivian Andes. Plant Ecology, 149, 181-193.

Kitayama, K. (1992). An altitudinal transect study of the vegetation on Mount Kinabalu, Borneo. Vegetatio, 102, 149-171.

Kitayama, K., \& Aiba, S. I. (2002). Ecosystem structure and productivity of tropical rain forests along altitudinal gradients with contrasting soil phosphorus pools on Mount Kinabalu, Borneo. Journal of Ecology, 90, 37-51. https://doi.org/10.1046/j.0022-0477.2001.00634.x

Le Quéré, C., Andrew, R., Canadell, J., Stich, S., Korsbakken, J., Peters, G. P., ... Zaehle, Z. (2016). Global carbon budget 2016. Earth System Science Data, 8, 605-649.

Lewis, S., Sonké, B., Sunderland, T., Begne, S., Lopez-Gonzalez, G., van der Heijden, G. M. F., ... Zemagho, L. (2013). Above-ground biomass and structure of 260 African tropical forests. Philosophical Transactions of the Royal Society B: Biological Sciences, 368, 20120295.

Lohbeck, M., Poorter, L., Martínez-Ramos, M., \& Bongers, F. (2015). Biomass is the main driver of changes in ecosystem process rates during tropical forest succession. Ecology, 96, 1242-1252.

Malhi, Y., Wood, D., Baker, T., Wright, J., Phillips, O., Cochrane, T., ... Vinceti, B. (2006). The regional variation of aboveground live biomass in old-growth Amazonian forests. Global Change Biology, 12, 1107-1138.

Malizia, A., Blundo, C., Carilla, J., Osinaga Acosta, O., Cuesta, F., Duque, A., ... Young, K. R. (2020). Elevation and latitude drives structure and tree species composition in Andean forests: Results from a large-scale plot Network. PLOS ONE, 15(4), e0231553. https://doi. org/10.1371/journal.pone.0231553

Malizia, A., Easdale, T. A., \& Grau, H. R. (2013). Rapid structural and compositional change in an old-growth subtropical forest: using plant traits to identify probable drivers. PLoS One, 8, e73546. https://doi. org/10.1371/journal.pone.0073546

Malizia, L., Pacheco, S., Blundo, C., \& Brown, A. D. (2012). Caracterización altitudinal, uso y conservación de las Yungas Subtropicales de Argentina. Revista Ecosistemas, 21, 53-73.

Miyamoto, K., Sato, T., Arana Olivos, E., Clostre Orellana, G., \& Rohner Stornaiuolo, C. (2018). Variation in tree community composition and carbon stock under natural and human disturbances in Andean Forests, Peru. Forests, 9(7), 390. https://doi.org/10.3390/f9070390

Myers, N., Mittermeier, R. A., Mittermeier, C. G., Da Fonseca, G. A., \& Kent, J. (2000). Biodiversity hotspots for conservation priorities. Nature, 403, 853-858.

Ortiz, G., Ramos, R. S., \& Alavar, A. (2017). Fire, rituals and domesticity. Forest resource management in the sub-Andean region of Jujuy, Argentina (2000BP): First anthracological evidence. Journal of Anthropological Archaeology, 47, 96-108.

Osinaga-Acosta, O., Báez, S., Cuesta, F., Malizia, A., Carrilla, J., Aguirre, N., \& Malizia, L. (2014). Monitoreo de diversidad vegetal y carbono en bosques andinos-Protocolo extendido. Protocolo 2 - Versión 1. CONDESAN / IER-UNT / COSUDE. Quito. 
Pan, Y., Birdsey, R. A., Fang, J., Houghton, R., Kauppi, P. E., Kurz, W. A., ... Hayes, D. (2011). A Large and Persistent Carbon Sink in the World's Forests. Science, 333, 988-993.

Peña, M., Feeley, K., \& Duque, A. (2018). Effects of endogenous and exogenous processes on aboveground biomass stocks and dynamics in Andean forests. Plant Ecology, 219, 1481-1492.

Phillips, O. L., Hall, P., Gentry, A. H., Sawyer, S. A., \& Vásquez, R. (1994). Dynamics and species richness of tropical rain forests. Proceedings of the National Academy of Sciences of the United States of America, 91, 2805-2809.

Poorter, L., van der Sande, M., Arets, E., Ascarrunz, N., Enquist, E., Finegan, B., ... Peña-Claros, M. (2017). Biodiversity and climate determine the functioning of Neotropical forests. Global Ecology and Biogeography, 26, 1423-1434.

Rahbek, C., Borregaard, M. K., Colwell, R. K., Dalsgaard, B., Holt, B., Morueta-Holme, N., ... Fjeldså, J. (2019). Building mountain biodiversity: Geological and evolutionary processes. Science, 365, 1114-1119.

Raich, J. W., Russell, A. E., Kitayama, K., Parton, W. J., \& Vitousek, P. M. (2006). Temperature influences carbon accumulation in moist tropical forests. Ecology, 87, 76-87.

Rapp, J., Silman, M., Clark, J., Girardin, C., Galiano, D., \& Tito, R. (2012). Intra- and interspecific tree growth across a long altitudinal gradient in the Peruvian Andes. Ecology, 93, 2061-2072.

Spracklen, D. V., \& Righelato, R. (2014). Tropical montane forests are a larger than expected global carbon store. Biogeosciences, 11, 2741-2754.

Stephenson, N., Das, A., Condit, R., Russo, S., Baker, T., Beckman, N. G., ... Zavala, M. A. (2014). Rate of tree carbon accumulation increases continuously with tree size. Nature, 507, 90-93.

Sullivan, M. J. P., Lewis, S. L., Affum-Baffoe, K., Castilho, C., Costa, F., Cuni-Sanchez, A., ... Phillips, O. L. (2020). Long-term thermal sensitivity of Earth's tropical forests. Science, 368, 869-874.

Unger, M., Homeier, J., \& Leuschner, C. (2012). Effects of soil chemistry on tropical forest biomass and productivity at different elevations in the equatorial Andes. Oecologia, 170, 263-274.
Valencia, R., Condit, R., Muller-Landau, H. C., Hernandez, C., \& Navarrete, H. (2009). Dissecting biomass dynamics in a large Amazonian forest plot. Journal of Tropical Ecology, 25, 473-482.

Vieira, S., Alves, L., Aidar, M., Araújo, L., Baker, T., Ferreira Batista, J. L., ... Trumbore, S. E. (2008). Estimations of biomass and carbón stocks: The case of the Atlantic forest. Biota Neotropica, 8(2), 21-29.

Vilanova, E., Ramírez-Angulo, H., Torres-Lezama, A., Aymard, G., Gámez, L., Durán, C., ... Ettl, G. J. (2018). Environmental drivers of forest structure and stem turnover across Venezuelan tropical forests. PLoS One, 13(6), e0198489. https://doi.org/10.1371/journal.pone.0198489

Wang, X., Piao, S., Ciais, P., Friedlingstein, P., Myneni, R. B., Cox, P., ... Chen, A. (2014). A two-fold increase of carbon cycle sensitivity to tropical temperature variations. Nature, 506, 212-215.

Werneck, F., Costa, G., Colli, G., Prado, D. E., \& Sites, J. W. (2011). Revisiting the historical distribution of Seasonally Dry Tropical Forests: New insights based on palaeodistribution modelling and palynological evidence. Global Ecology and Biogeography, 20, 272-288.

Zhang, C., Ju, W., Chen, J., Wang, X., Yang, L., \& Zheng, G. (2015). Disturbance-induced reduction of biomass carbon sinks of China's forests in recent years. Environmental Research Letters, 10, 114021.

\section{SUPPORTING INFORMATION}

Additional supporting information may be found online in the Supporting Information section.

How to cite this article: Blundo C, Malizia A, Malizia LR, Lichstein JW. Forest biomass stocks and dynamics across the subtropical Andes. Biotropica. 2020;00:1-9. https://doi. org/10.1111/btp.12858 